\title{
THE CREATION OF DIGITAL IMAGE OF CULTURAL HERITAGE: WORLD AND DOMESTIC EXPERIENCE (The Information Base of the Cultural Heritage Case of Sites of Kyiv)
}

\begin{abstract}
The article outlines the urgent problems of the protection and preservation of cultural heritage objects, it is emphasized that one of the priority areas of modern monument protection work is the transmission to future generations the historical knowledge embodied in these objects, historical information about them. The purpose of the research is to highlight domestic experience of implementation and development of the electronic accounting of monuments of cultural heritage by the case of "The Information Base of the Cultural Heritage of Kyiv City". The research methodology. A set of general scientific and special methods was applied. The principles of historicism, scientific objectivity and system are taken as a basis, the systematization of factual material, the processing and compilation of accumulated information, the conceptual generalization of the original factual material are carried out. The scientific novelty. Foreign experience of creation and functioning of electronic databases of objects of cultural heritage is described: the French state database of the French Ministry of Culture and the Heritage Department "Merimee", the state English electronic base "Monarch", the Flanders state federal electronic database (part of Belgium) "Melanie", and the Russian federal database "Monuments of Russia". Conclusions. In the article the author made an attempt to characterize briefly the problems of implementation the electronic databases of cultural heritage in Ukraine. The role of the information product - the program module "The Information Base of the Cultural Heritage of Kyiv City" is revealed, which is actively implemented in practical activities in the field of cultural heritage protection and greatly contributes to optimization of work in this area, by the example of the work of the State Historical and Architectural Reserve "Ancient Kyiv". The conclusions expressed that the information field of cultural heritage is not standardized today, not a single cultural heritage protection agency has comprehensive information on the state of affairs in this area. But the general global trend is not only the formation of national electronic registers, but also consolidated international data banks on objects of cultural heritage.
\end{abstract}

Keywords: electronic databases, protection of cultural heritage, monuments of architecture, cultural heritage sites, information product, software module.

The determination of the problem. The question of the preservation of cultural heritage and awareness of society, its importance as an indicator of self-identification and an important conglomerate component is one of the main strategic tasks of the contemporary Ukrainian cultural policy supported by a large number of Ukrainians, as specialists in this area, by amateurs and ordinary citizens.

The confirmation of these theses is the statistical information of 2016-2018, which indicate a sufficiently high level of interest of Ukrainians in cultural 
heritage. And the indicators of the survey results demonstrate a positive dynamics of the growth of Kyiv's interest in the monuments of cultural heritage in $2016-64 \%$, in $2017-65,5 \%$, in 2018 it reached $78 \%$ (according to the press releases and reports of the Kyiv International Institute of Sociology).

The analysis of recent researches and publications. A number of domestic researchers worked on the development of electronic databases for cultural heritage sites: M.Levada, V.Pioro, O.Popelnytskyi, M.Potupchik etc. However, the study of this issue, the coverage of the problems and the analysis of the functionality of this base for practical study of monuments from the viewpoint of the user, ordinary citizen or specialist in history, practice of monument protective almost wasn't engaged, except the Ukrainian historians, S.Kot, I.Abramova, O.Tytova, foreign researchers - P.Grinfeld, L.Kudriavtsev, A.Margolis, B.Kirikov, L.Petrov.

The emphasis of previously unsettled parts of the general problem. In view of the analysis of publications, it becomes clear that the problematics are not sufficiently researched in scientific historiography. The main array of information is presented on the Internet resources, most of which are a direct source that is a site with a database of cultural heritage, presented in different European countries, as well as in Russia and Ukraine.

The formulation of the goals of the article (problem statement). The purpose of this article is to open one of the important issues in the sphere of cultural heritage, namely, the problem of information storage about cultural heritage monuments. The topic is relevant in consideration of the political and economic situation in the country, which in recent years leads to a devastating decline in in the financing of various types of monument protective research and restoration work. The technical condition of most museums, archives, libraries and archival repositories of certain state institutions in Kyiv deteriorate, the number of qualified specialists decreases, and the information available in the archives often remains unworkable and inaccessible due to the lack of a think over search and inquiry procedure. That is why, today one of the priority directions of monument protective is an attempt not only to provide the most effective mechanism of monument protection and maintenance at the appropriate level but also to preserve information about these objects.

The representation of the main research material. Today, the information about historical objects is actually located in various organizations, both state structures and private firms, and the access to it is complicated for specialists and a wide range of the population. As before, storage, classification, registration and other forms of data recording of cultural heritage monuments and objects is implemented through the paper medium of information - printed texts, photographs, drawings. Accordingly, such medium has a number of disadvantages, due to its physical particularities, it is often centered on different institutions, which complicates the search, selection, systematization, and the use of necessary data.

The replacement solution from the situation is possible only on the basis of the transition to new methods of storage and work with information. Given the particulars of information about monuments (which contains text and graphics data), the modern electronic form of information organization and storage 
has the following advantages: practically removes restrictions on the amount of stored information; information is not related to the material value of its carrier; convenience of data structuring and search organization; adaptation of material for each consumer, orientation to a specific group of problems.

Today, the problem of information storage about the monuments are engaged in a number of developers of electronic systems. An overview of foreign and domestic experience in this area, as well as an analysis of the practical activities of the relevant structures concerning the storage and use of information about cultural heritage, forms twofold, though polar views on two forms of information storage - the traditional form (paper carriers) and electronic. In most countries with medium-sized economies, the first form is attracted and remains the main and obligative of saving money, that is, because of the limited funding of the cultural sector. In some more developed countries, against the backdrop of a diminution of interest in electronic databases, which boomed in the 80's and 90's of the twentieth century, almost simultaneously, both forms of information storage are used. These countries are experiencing a second qualitatively new stage in the development of electronic databases from cumbersome and costly to simplified, multi-level flexible programs, which generally use rather short but well-structured databases for administrative security and scientific purposes.

In general, in most developed countries of Europe and in the United States, with the monument protective authorities created the professional closed databases of a new generation with a wide range of search capabilities. In this case, as a rule, all information is divided into several levels of access, differing in the composition of information and the degree of openness - the most informative-saturated level is accessible to a narrow circle of official representatives or employees of the services of monument protective and it is strictly regulated.

"Merimee" ("Merime") is a French state database of the Ministry of Culture of France and of the Department of Heritage created in the 1990's. Today, the database functions as a classic archive with paid and free services ${ }^{1}$.

"Monarch" is a state-owned English electronic database created in the mid1990s at the Royal Commission of Historic Sites of England. In terms of activity, openness and structure, it is close to the "Merimee" database 2 .

"Melanie" - Federal Governmental Electronic Base of Flanders (part of Belgium) established in 1998. It has a three-tier system: the first (for officials, civil servants) includes a database of the National Register of Cultural property, information on the financial system of protection and management of monuments of the highest category; the second (for representatives of monument protective agencies, cultural workers), includes detailed information on cultural property which are in state protection, this level is closed for ordinary citizens in order to protect the rights of owners for detailed information about their

${ }^{1}$ Іванюта I.B., Шпарага T.I. Організація музейної справи у Франції та їі досвід для України. - К., 2014. - C.549-552 [Електронний ресурc]: http://geopolitika.crimea.edu/arhiv/2014/ tom10-v-2/0100ivanyuta.pdf

2 Рутинський М.Й., Стецюк О.В. Музеезнавство. - К., 2008. - С.127-141. 
property, financial documents; the third level (for the general public) contains limited structured information about the objects.

"The monuments of Russia" is a Russian federal database created in 1997. The materials on the inheritance are laid down in the form of a short list. The search is possible with a limited range of parameters: the historical name of the object, address, category of protection, date and personality of the architect. All names of monuments are not structured ${ }^{3}$.

In Ukraine, issues of electronic accounting of monuments and the creation of the electronic database began to take place in the late 90's. Since 1995, the Office of the Heritage Preservation of Kyiv and the Kyiv Scientific and Methodological Center for the Heritage Preservation have been working on the issue of accounting computerization; initially, only Lists of Kyiv monuments, formed on the basis of government decisions accepted since 1963, and Lists of newly discovered objects. Later, registration cards and passports were transferred to the electronic form. The next stage of work on the creation of the program began in 1999 . By funds of the Kyiv Scientific and Methodological Center, with the involvement of experts from the Institute of Monument Protective Studies of the Ministry of Culture, was created a database of "Sights of Kyiv" which worked in the Microsoft Access environment and allowed to receive and print the necessary reports ${ }^{4}$.

Interesting in the context of considering the issue of implementing the electronic form of the Register are the practices of the Ukrainian Center for Cultural Studies, in 2017, working towards standardization of metadata and data exchange in the context of creating of the electronic information resource for cultural heritage and cultural assets. The purpose of this work was the formation a unified conceptual framework for the introduction and development of electronic accounting of cultural heritage monuments in Ukraine taking into account current world trends, the development of unified metadata schemes for the electronic accounting of immovable monuments and the exchange of data. Within the framework of the given work was analyzed the current procedure for recording immovable objects of cultural heritage, was developed a formalized model of basic accounting processes taking into account the needs of digitalization, and analyzed international (European) standards of metadata for the description, accounting and presentation of cultural heritage objects, the scheme of metadata has been developed taking into account the relevant European experience, was defined the basic requirements for the unified data exchange on immovable objects in the context of accounting procedures and with the object of forming the information resource of cultural heritage (set of xml-schemes "HED"). The formalized electronic model of accounting processes is a necessary basis for modernizing the accounting of immovable cultural heritage monuments,

${ }^{3}$ Гринфбельд П.А., Кириков Б.М., Петров Л.В. Опыт создания и ведения полной базы данных памятников архитектуры, истории и культуры Санкт-Петербурга с использованием электронной карты // Международная конференция “Проблемы и решения: Информационные и коммуникационные технологии", г. Санкт-Петербург, 3-8 декабря 2001 г. [Електронний pecypc]: https://eva.rsl.ru/old/evarussia/eva2001/russian/rasp_1.html

${ }_{4}^{4}$ Абралиова I.B. Новий підхід до вирішення проблем обліку пам'яток в м. Киеві // Культурна спадщина Киева: Дослідження та охорона історичного середовища. - К., 2003. - С.22-24. 
providing multilevel electronic interactions in the field of cultural heritage protection and creating a state information resource for cultural heritage and cultural assets. Consequently, within the framework of the proposed work of the Ukrainian Center of Cultural Studies of the MCU was realized the formalization of the accounting processes of cultural heritage objects and related data structures, was developed a project of national scheme of metadata for the description and accounting of cultural heritage objects. The model CIDOC CRM model (www.cidoc-crm.org, ISO 21127: 2014) was chosen as the basic formalized ontology as the conceptual basis of the work. The obtained results create the conditions for ensuring technical and semantic interoperability in the field of cultural heritage protection, integration with international data banks. The implementation of the results of this work, in particular, the Unified Metadata Scheme (set of xml-schemes), will have direct practical benefits for the formation of multilevel electronic interactions in the area of accounting of cultural heritage objects, the formation of the state electronic resource of cultural heritage and cultural assets, will contribute to ensuring a new quality of access to information and increase efficiency of administration in the field of culture on the principles of e-governance. At the same time, today the Ministry of Culture considers the issue of creating a reference information database of immovable cultural heritage in the context of the creation of an electronic information resource of cultural heritage, which develops to implement the Medium-Term Plan of Government Priorities for 2020, approved by the The Cabinet of Ministers of Ukraine Order No.275 of April 3, 2017.

In 2018, the specialists working on the program module "Information Base of the Cultural Heritage Sites of Kyiv" approached the problem of creating a database. During the creation of the "Sights" module, specialists were guided by the following normative legal acts: the Law of Ukraine "On the Protection of the Cultural Heritage", the Law "On Information", the Law "On the National Program of Informatization", the Law on "Electronic Documents and Electronic Document Circulation"; Order of the Ministry of Culture of Ukraine "On approval of the rules for the Accounting of Objects of the Cultural Heritage" and "On approval of the forms of the Registration Card and Passports of the Cultural Heritage Object"; Decree of the Cabinet of Ministers of Ukraine dated 28.12.2001 No.1768 "On approval of the procedure for the conclusion of protection contracts for cultural heritage monuments", as well as from dated 29.03.2006 No.373 "On the approval of the Rules for the protection of information in informational, telecommunication and informational and telecommunication systems". The national and international standards: Ukraine standards 2394-94 "The information and the documentation. The fund complecting, bibliographic description, document analysis. The terms and definitions"; Ukraine standards 3396.0-96 "The Information Protection. Technical protection of information. Substantive provisions"; Ukraine standards 2873-94 "The Systems of information processing. The programming. The terms and definitions"; GOST (technical standards) 34.003-90 "The Information technology. A set of standards for automated systems. The automated systems. The terms and definitions" and others. 
The module is a programmatic resource of the territorial community of the city of Kyiv that allows to enter, store and process official information on cultural heritage monuments of the city of Kyiv in the information and analytical system "The Management of the property complex of the territorial community of the city of Kyiv". It carries out a number of tasks: 1 ) the raising the awareness of the Kyiv city community about the status of cultural heritage monuments of Kyiv, the activities of the cultural heritage protection authorities in preserving historical monuments of the city and violations committed in relation to these monuments; 2) the creation of conditions for public control over the preservation of monuments of cultural heritage; 3 ) the increase of information openness and transparency in the activities of the bodies of cultural heritage protection.

The conclusions from this study. The general global trend is not only the formation of national electronic registers, but also consolidated international data banks on cultural heritage objects (mobile, immovable, intangible). The fundamental basis for this is the consistent development of the theoretical and methodological basis, profile standards for ontologies and metadata.

Therefore, it can be stated that current processes of accounting of monuments and registration of information disagree the modern challenges and needs of society, do not give an idea of the real state of cultural heritage objects. The lack of clear and transparent mechanisms for the formation of actual data sets and ensuring public access to them increases the risk of corruption and abuses in the area of the conservation and use of cultural heritage objects.

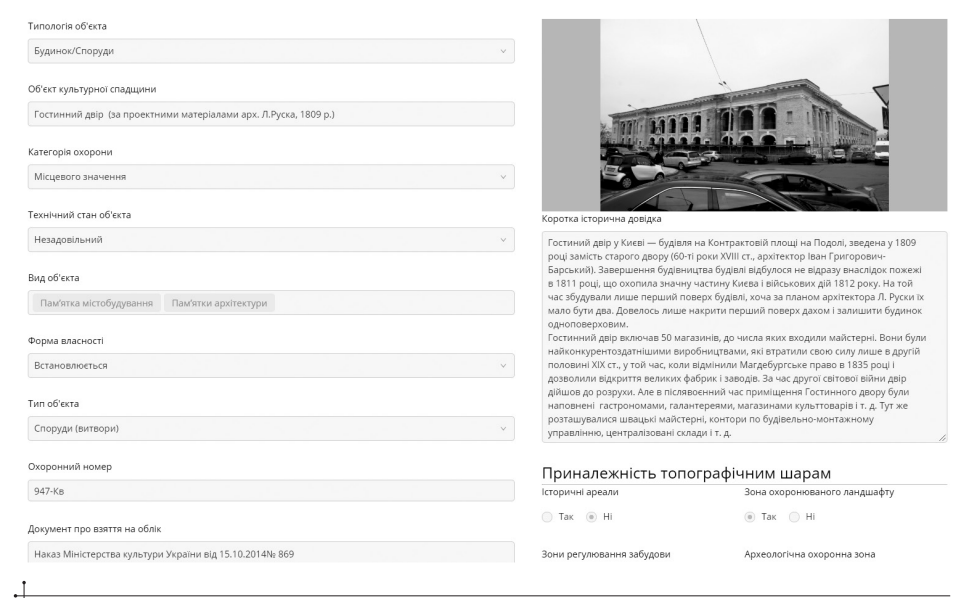

1. View of the "Information Base of the Cultural Heritage of Kyiv City" for internal user

In summary, today the program module "The Information Base of the Cultural Heritage of Kyiv City" is completed with an information product that is actively being implemented in the field of cultural heritage protection, which will greatly facilitate the optimization of work in this area, will improve the accounting, will give a complete picture of the state of affairs with the protection and preservation of the cultural heritage of the city, will help plan work on repair and restoration of objects. Thanks to the information base, international cooperation and the exchange of information on the protection and preservation of cultural heritage will spread ${ }^{5}$.

5 Рішення від 20 грудня 2016 р. №774/1778 “Про створення единої інформаційної бази пам'яток культурної спадщини міста Києва” [Електронний ресурс]: http://kmr.ligazakon.ua/ SITE2/1_docki2.nsf/alldocWWW/30D30E41D9CAF72FC22580B9003C753B?OpenDocument 


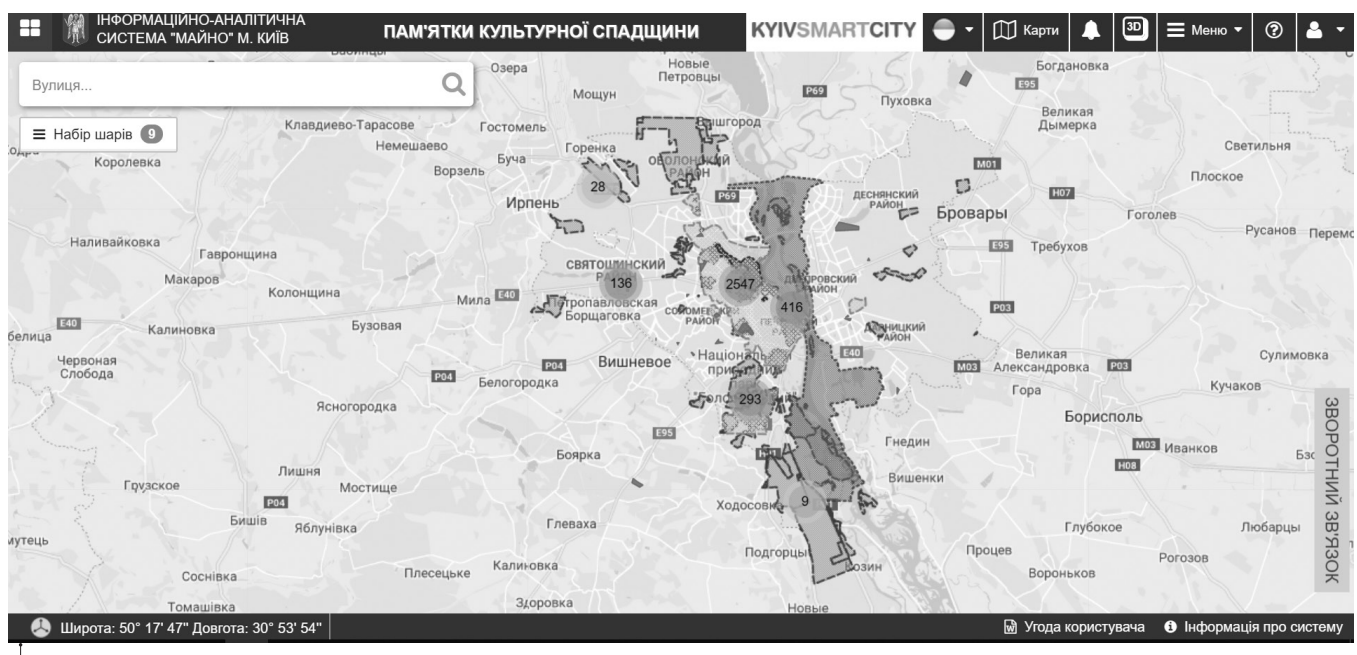

2. View of the "Information Base of the Cultural Heritage of Kyiv City" for external user

The specialists of Kyiv scientific methodological center, as well as employees of the State Historical and Architectural Reserve "The Ancient Kyiv", work on filling the base. To date, the information on objects of cultural heritage located on the territory of the State Historical and Architectural Reserve "The Ancient Kyiv" (total - 358, archaeology - 39, history - 13, architecture - 293, monumental art - 10, landscape - 1, science and technology -2) has been completely included, it is carried out the active work on the filling of the Gallery, registration cards and passports, the acts of technical condition, restoration tasks, scientific and project documentation, the information about owners and users of objects, protection contracts, etc. (see screenshot 1). The completion of work on the filling of the information base is planned for the end of the second quarter of 2019. It should be noted that the database is not a repository of stable information, it is positioned not only as lists of objects, but as elements of a distributed multi-level dynamic system of generation, circulation and aggregation of relevant data (see screenshot 2$)^{6}$. The database operates on the basis of the following principles: relevance, authenticity, completeness and integrity of the data; availability of open data; interoperability.

\section{REFERENCES}

1. Ivaniuta, I., Shparaha, T. (2014). Orhanizatsiia muzeinoi spravy u Frantsii ta yii dosvid dlia Ukrainy. Heopolityka i ekoheodynamika rehioniv, 10, 549-552. Retrieved from: http://geopolitika.crimea.edu/arhiv/2014/tom10-v-2/0100ivanyuta.pdf [in Ukrainian].

2. Rutynskyi, M.Y. \& Stetsiuk, O.V. (2008). Muzeieznavstvo: Navch. posib. Kyiv. [in Ukrainian].

${ }^{6}$ Інформаційно-аналітична система "Майно”: Пам'ятки міста Києва [Електронний ресурс]: https://gis.kyivcity.gov.ua/ 
3. Grinfeld, P.A., Kirikov, B.M, Petrov L.V. (2001). Opyt sozdaniya i vedeniya polnoj bazy dannykh pamyatnikov arhitektury, istorii i kultury Sankt-Peterburga s ispolzovaniem elektronnoj karty. Mezhdunarodnaya konferentsiya: Problemy i resheniya: Informatsionnye $i$ kommunikatsionnye tekhnologii (Sankt-Peterburg, 3-8 dekabrya 2001 g.). Retrieved from: https://eva.rsl.ru/old/evarussia/eva2001/russian/rasp_1.html [in Russian].

4. Abramova, I.V. (2003). Novyi pidkhid do vyrishennia problem obliku pamiatok v m. Kyievi. Kulturna spadshchyna Kyieva: doslidzhennia ta okhorona istorychnoho seredovyshcha. Kyiv. [in Ukrainian].

\title{
АНАСТАСІя ГОРЬКОВА
}

кандидатка історичних наук, учена секретарка,

Центр пам'яткознавства НАН України і УТОПІК

(Київ, Україна), Anas7asik@gmail.com

ORCID: https://orcid.org/0000-0002-7306-4000

\section{ТВОРЕННЯ ЦИФРОВОГО ОБРАЗУ КУЛЬТУРНОЇ СПАДЩИНИ: СВІТОВИЙ І ВІТЧИЗНЯНИЙ ДОСВІД (Інформаційна база культурної спадщини на прикладі пам'яток міста Києва)}

\begin{abstract}
Анотація. Мета дослідження - висвітлити вітчизняний досвід упровадження та розвитку електронного обліку пал'яток культурної спадщини на прикладі "Інфбормаиійної бази пал'яток культурної спадщини міста Києва". Методологія дослідження. Застосовано колплекс загальнонаукових і спеціальних методів. За основу взято приниипи історизлу, наукової об'єктивності та систелності, здійснено систелатизацію фбактологічного матеріалу, опрацювання й упорядкування накопиченої інформацї, проведено концептуальне узагальнення вихідного фбактичного матеріалу. Наукова новизна. У статті висвітлено закордонний досвід створення та фбункиіонування електронних баз даних об'єктів культурної спадщини. Розкрито історію становлення, трансборлації електронних баз даних культурної спадшини в Україні, охарактеризовано проблели їх упровадження. Висвітлено напрацювання Украӥнського иентру культурних досліджень Міністерства культури України в 2017 р., що працював у напрялі стандартизаиї метаданих та обміну даними в контексті створення електронного інфбормаційного ресурсу об'єктів культурної спадщини та культурних иінностей. Висновки. Виявлено роль інфборлаційного продукту - «Інфборлаційної бази пал'яток культурної спадшини міста Києва", який активно впроваджуеться у практичну діяльність у галузі охорони культурної спадщини. База є програлнил ресурсол територіальної гролади міста Києва, що дозволяе вносити, зберігати, опрацьовувати оббіиійн інфборлацію щодо пал'яток культурної спадшини Киева в інфбормаційно-аналітичну систелу "Управління майновил колплексол територіальної гролади міста Києва". Доведено, що означений модуль сприяє оптилізаиї роботи у иій сбері на прикладі Державного історико-архітектурного заповідника "Стародавній Київ". Зазначено, що інфборлаиійне поле пал'яткоохоронної галузі залишається на сьогодні нестандартизованил, жоден орган охорони культурної спадщини не володіє вичерпною інборлацією про стан справ у иій собері, що актуалізуе розробку відповідних баз не тільки для нерухолих, але й для рухомих пал'яток культурної спадшини.
\end{abstract}

Ключові слова: електронні бази даних, охорона культурної спадшини, пал'ятки архітектури, об'єкти культурної спадщини, інфборлаиійний продукт, програлний модуль. 